Japan. J. Med. Sci. Biol., 24, 295-311, 1971

\title{
PLAQUE CHARACTERISTICS OF COXSACKIE A7 VIRUS
}

\author{
KENJI SODA \\ The Institute of Medical Science, The University of Tokyo, \\ Minato-ku, Tokyo 108, Japan \\ (Received: July 20th, 1971)
}

\begin{abstract}
SUMMARY: Conditions for the production of plaques by cytopathogenic strains of coxsackie A 7 (CA 7) virus were examined, and plaque characteristics and biological properties of the virus strains were studied. Out of 14 strains of $\mathrm{CA} 7$ virus, $\mathrm{AB}-\mathrm{IV}-\mathrm{KH}$ and two lines of the prototype strains showed remarkable heterogeneity in size of plaques in monkey kidney cells, while the other strains produced uniform, small plaques only. An appropriate concentration of DEAEdextran or protamine sulfate in the agar overlay enhanced significantly the formation of plaques by these strains, especially of small plaques, and the concentration of sodium bicarbonate in the agar overlay was also proved to be one of the important factors affecting the plaque formation of the virus. A large plaqueforming (LP) and a small plaque-forming (SP) viruses were obtained from ABIV-KH strain by serial plaque purifications or terminal dilution passages. LP virus was genetically less stable than SP virus, and plaque production of SP virus was significantly enhanced by DEAE-dextran or protamine sulfate and reversely inhibited by agar extract or sulfated polysaccharides. No differences in growth rate in monkey kidney cell cultures, serological property or pathogenicity in suckling mice were observed between LP and SP viruses.
\end{abstract}

\section{INTRODUCTION}

Coxsackievirus group A 7 (CA 7) is considered to be one of the most important viruses besides poliovirus in that it causes polio-like paralysis in man (Voroshilova and Chumakov, 1959). This virus is usually pathogenic only to suckling mice, cotton rats (Voroshilova and Chumakov, 1959) and merion (Grist and Roberts, 1966) among experimental animals other than primates. After several serial passages in primary monkey kidney (MK) cell cultures it becomes to replicate well and to manifest cytopathic changes (Habel and Loomis, 1957). No other report than that by Koroleva et al. (1968), however, concerning the plaque formation of CA 7 virus has ever appeared. They described that no or indistinct plaques were produced by $\mathrm{MK}$ cell-adapted prototype strain of CA 7 virus, and plaque formation was not enhanced by the addition of DEAE-dextran up to $100 \mu \mathrm{g} / \mathrm{ml}$ in the agar overlay. The present author found that AB-IV strain produced heterogeneous plaques under agar overlay and obtained a large plaque (LP) and a small plaque (SP) viruses by plaque purifications or terminal dilution

Present Address: Gunma Prefectural Institute of Health, Iwagami-cho, Maebashi-shi, Gunma 371, Japan

曽田 研二 (東京大学医科学研究所 港区白金台町) 
Table 1. Name and source of coxsackie A7 virus strains used

\begin{tabular}{|c|c|c|c|c|c|c|}
\hline & & & Isola & lation & & \\
\hline Strain nam & & Year & Place & $\begin{array}{l}\text { Source } \\
\text { of } \\
\text { specimen }\end{array}$ & Method & Clinical diagnosis \\
\hline $\begin{array}{l}\text { AB-IV-KH, } \\
\quad \text { No. } 2435 \\
\text { AB-IV-LP } \\
\text { AB-IV-SP } \\
\text { AB-IV-CH } \\
\text { AB-IV-2812 }\end{array}$ & $\begin{array}{l}\text { 2) } \\
\text { 3) }\end{array}$ & 1952 & $\begin{array}{l}\text { Karaganda } \\
\text { U.S.S. R. }\end{array}$ & $\begin{array}{l}\text { pooled } \\
\text { feces } \\
\text { from } \\
\text { two } \\
\text { patients }\end{array}$ & $\begin{array}{l}\text { rhesus } \\
\text { monkey }\end{array}$ & $\begin{array}{l}\text { paralytic } \\
\text { poliomyelitis }\end{array}$ \\
\hline $\begin{array}{l}\text { Moscow-119 } \\
\text { Moscow-172 }\end{array}$ & & $\begin{array}{l}1960 \\
\text { "I }\end{array}$ & $\begin{array}{l}\text { Moscow, } \\
\text { U.S. S. R. } \\
\quad \text { "I }\end{array}$ & $\begin{array}{c}\text { feces } \\
\quad " \prime\end{array}$ & $\begin{array}{c}\text { cotton rat } \\
\text { II }\end{array}$ & $\begin{array}{c}\text { poliomyelitis } \\
\text { /I }\end{array}$ \\
\hline $63-G-35-4$ & & 1963 & Kawasaki & feces & MKTC & healthy \\
\hline Natori-32 & 4) & " & Miyagi & " & " & "I \\
\hline Z-C-52-7 & & 1961 & Nagaoka & " & "I & "I \\
\hline Z-C-61-7 & & " & "l & " & "I & "I \\
\hline Hale & 5) & 1957 & $\begin{array}{l}\text { California, } \\
\text { U. S. A. }\end{array}$ & feces & $\begin{array}{l}\text { suckling } \\
\text { mice }\end{array}$ & $\begin{array}{l}\text { non-paralytic } \\
\text { polio }\end{array}$ \\
\hline NYS-58180 & 5) & 1958 & $\begin{array}{l}\text { N. Y. State } \\
\text { U. S. A. }\end{array}$ & " & "I & $\begin{array}{l}\text { benign } \\
\text { meningitis }\end{array}$ \\
\hline NYS-58182 & 5) & " & " & "I & " & $\begin{array}{l}\text { aseptic } \\
\text { meningitis }\end{array}$ \\
\hline Parker-CDC & & 1948 & $\begin{array}{l}\text { Coxsackie, } \\
\text { N. Y. City, } \\
\text { U. S. A. }\end{array}$ & feces & $\begin{array}{l}\text { suckling } \\
\text { mice }\end{array}$ & $\begin{array}{l}\text { aseptic } \\
\text { meningitis }\end{array}$ \\
\hline Parker-Moscc & & & & & & \\
\hline
\end{tabular}

1-3) Received from Dr. M. K. Voroshilova, Institute of Poliomyelitis and Viral Encephalitis, Moscow, U. S. S. R. as MK-cell adapted virus.

1) Received in 1961 together with the prototype Parker-Moscow. 2) Received in 1964. 3) Received in 1965 together with the MK-cell adapted viruses, Moscow119 and Moscow-172. 4) Received from Dr. H. Ujiie, Miyagi Institute of Public Health, Sendai. 5) Received from Dr. H. A. Wenner, University of Kansas, U. S. A. as MK-cell adapted virus.

passages. By the use of these viruses, the basic conditions for the production of plaques as well as various biological properties of the viruses were investigated. The report also includes the characteristics of plaques, produced by various MK cell-adapted CA 7 strains including the prototype strain, which were without exception enhanced by the addition of DEAE-dextran in the overlay.

\section{MATERIALS AND METHODS}

Virus strains: The strains used in this study are listed in Table 1. The AB-IV 
strain (Chumakov et al., 1956) at 3 different passage levels was supplied by Dr. M. K. Voroshilova, Institute of Poliomyelitis and Viral Encephalitis, Moscow, U.S.S. R. From the AB-IV-KH, No. 24351 strain at a lower passage level in MK cells than the other two pedigreed strains, AB-IV-CH and AB-IV-2812, large- and small-plaque forming viruses, AB-IV-LP and AB-IV-SP, were obtained as will be described later. The prototype strain was obtained in 1961 from two different sources, Dr. H. Gelfand, Communicable Disease Center (CDC), Atlanta, U. S. A. and Dr. Voroshilova, as infected suckling mouse suspensions and later adapted to MK cells by 6 serial passages in our laboratory. These were designated as Parker-CDC and Parker-Moscow, respectively.

Tissue cultures and media: Trypsinized cynomolgus monkey kidney (MK) cells were grown in $0.5 \%$ lactalbumin hydrolysate Earle's saline (LE) containing $2 \%$ bovine serum. The cell cultures in $2 \mathrm{oz}$. prescription bottles or tubes $(15 \times 150 \mathrm{~mm})$ were incubated for 6 to 7 days at $36 \mathrm{C}$ before use. One day before virus inoculation the growth medium was replaced with fresh serum-free medium. After virus inoculation cultures were maintained in serum-free medium.

Antisera: The rabbit antisera against AB-IV-KH, AB-IV-LP and AB-IV-SP viruses were prepared in our laboratory. Culture fluids harvested from MK cell cultures infected with viruses were used as antigens, and all animals were immunized by repeated intravenous inoculation of viruses and bled one month after the initial injection.

Plaque formation: After maintenace medium was discarded, monolayer cells in a $2 \mathrm{oz}$. bottle were inoculated with $0.2 \mathrm{ml}$ of virus fluid and incubated at $36 \mathrm{C}$ for 1 hr. After virus adsorption, each culture bottle received $5 \mathrm{ml}$ of overlay medium. The overlay medium consisted of Parker's medium 199, supplemented with $0.1 \%$ bovine albumin fraction $\mathrm{V}$ (BAFV) (Nutritional Biochemical Corp.), $0.002 \%$ neutral red, $0.22 \% \mathrm{NaHCO}_{3}$ and antibiotics, and $1.5 \%$ agar (special agar-Noble (Noble-agar) or Bacto-agar, DIFCO Laboratories) (Dulbecco and Vogt, 1954), $1.8 \%$ carboxy-methylcellulose (CMC) SM 4000 (Shin' etsu Chemical Co.) (Tytell and Neuman, 1963) or $10 \%$ potato starch gel solution (De Maeyer and Schonne, 1964) as a solidifying agent. Drugs affecting plaque formation were added to overlay medium when needed.

Drugs affecting plaque formation: DEAE-dextran MW $2 \times 10^{6}$ (Pharmacia) and salmon protamine sulfate 2000 (Pharmacia) were used as plaque enhancers. Dextran sulfate 2000 (Pharmacia), heparin sodium (NBC) and self-made ethanol extract of Bacto-agar (Agol and Chumakova, 1962) were used as plaque inhibitors.

Procedures for isolation of LP and SP mutants: The LP and SP viruses were derived from a parent virus, AB-IV-KH strain, as shown in Fig. 1. The SP strain was obtained by limiting dilution passages. The virus was diluted serially by 10 -fold and 10 tube cultures of $\mathrm{MK}$ cells were used per dilution. One of the tubes at the highest dilution manifesting complete CPE was harvested. The supernatant fluid obtained by two alternate cycles of freezing and thawing of the whole cell cultures harvested was transferred to the next passage. After four limiting dilution passages the resulting virus harvest underwent two more passages in bottle cultures of MK cells to prepare a working stock of SP virus. LP virus was obtained by plaque purification. The plaque formation was performed in MK bottle cultures under standard Noble-agar overlay containing no enhancer. The starting virus, AB-IV-KH strain, diluted serially by 10 -fold, produced plaques, heterogeneous in size, of which the largest plaque was picked up from cultures. The harvested plaque suspended 
Fig. 1. Isolation of AB-IV-LP and AB-IV-SP viruses

Parent, AB-IV-KH 24351*

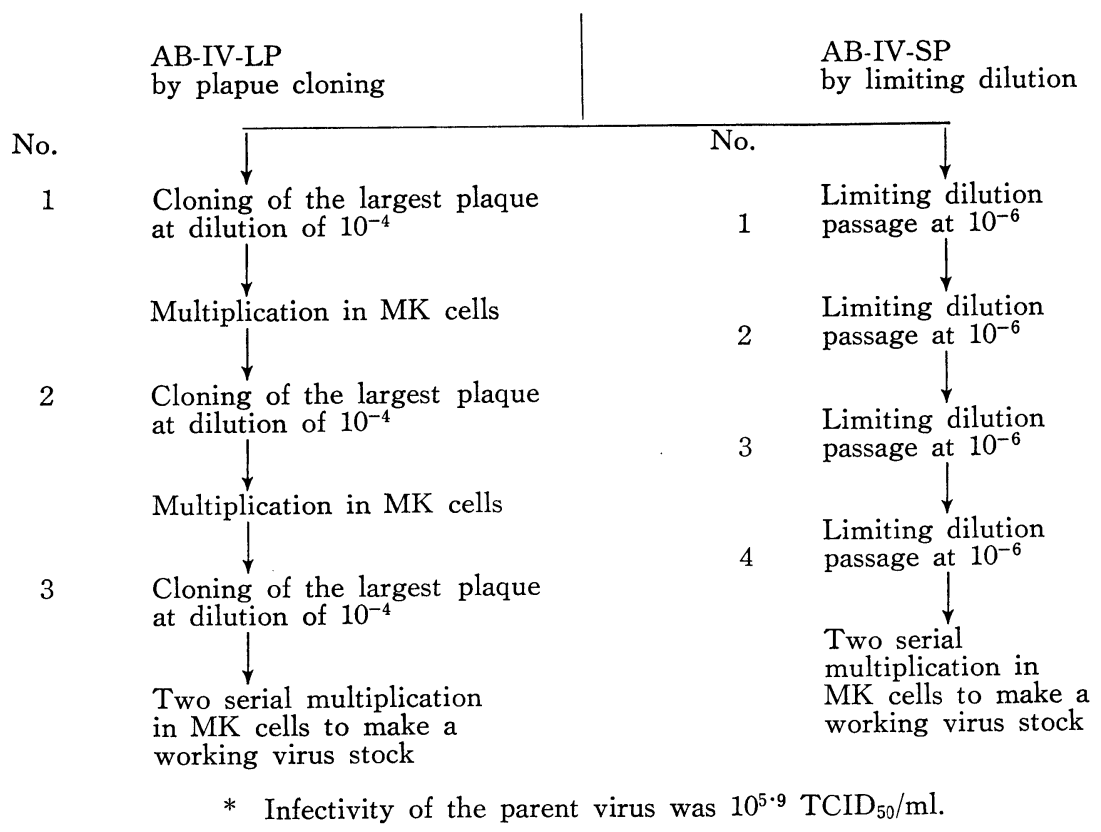

in the medium underwent one passage in tube cultures before the next cloning passage. After three repeated plaque clonings the virus underwent two more passages in MK bottle cultures to prepare a working stock of LP virus.

Infectivity titrations: For plaque assay viruses were diluted serially by 10 -fold and 5 bottles were used per dilution. Tube titration was carried out as follows; $0.2 \mathrm{ml}$ of serial decimal dilutions of virus was inoculated into each of 10 tube cultures per dilution containing $1 \mathrm{ml}$ of fresh serum-free LE medium and incubated at $36 \mathrm{C}$ for 6 days. Cytopathic changes were finally read on the 6 th day and infectivity titers were determined (Reed and Muench, 1938).

Neutralization tests: A serum after inactivation at $56 \mathrm{C}$ for $30 \mathrm{~min}$ was examined in 4 -fold serial dilutions. To the diluted serum an equal volume of virus suspension containing $100 \mathrm{TCID}_{50} / 0.1 \mathrm{ml}$ in the tube method or $100 \mathrm{PFU} / 0.1 \mathrm{ml}$ in the plaque assay was added. The mixtures were incubated at $36 \mathrm{C}$ for $3 \mathrm{hr}$, and then kept standing overnight at $4 \mathrm{C}$. For the tube neutralization test $0.2 \mathrm{ml}$ of the mixtures was inoculated into each $\mathrm{MK}$ cell tube culture containing $1 \mathrm{ml}$ of maintenance medium; four tubes were employed per serum dilution. The inoculated cultures were kept at $36 \mathrm{C}$, and the tests were read when the titer of virus control reached $100 \mathrm{TCID}_{50} /$ $0.1 \mathrm{ml}$ after 4 to 6 days. The antibody titer was expressed as the reciplocal of $50 \%$ neutralization end point of the serum dilution. For the plaque neutralization test, $0.2 \mathrm{ml}$ of the virus-serum mixture was inoculated into each bottle culture and assayed in the same way as described for the plaque infectivity titration. On the 6 th day plaques were counted and percent reduction of plaques was determined. 


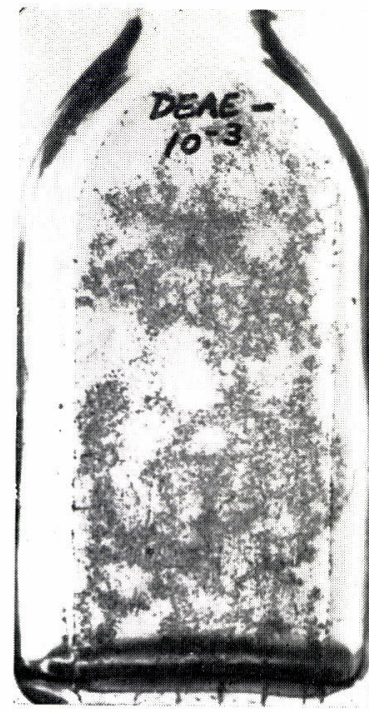

Dilution: $\quad 10^{-3}$

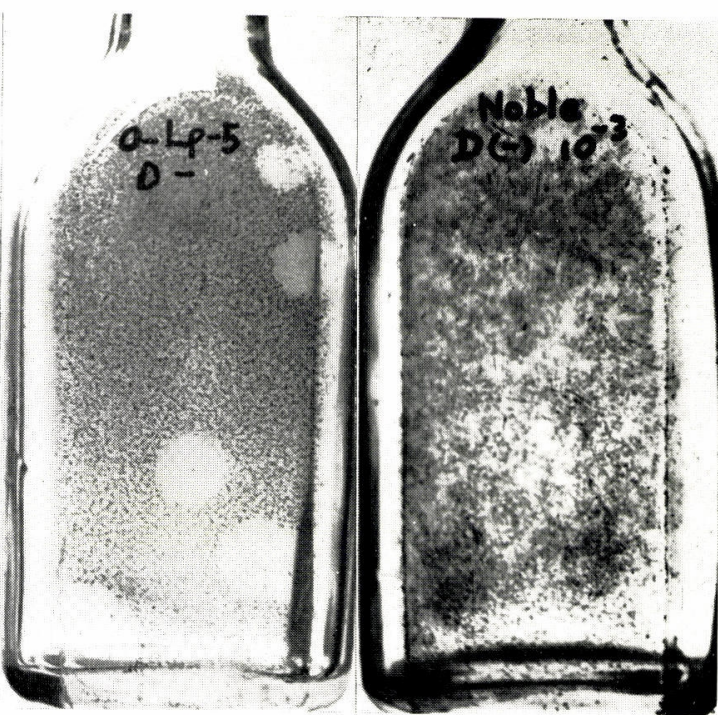

$10^{-3}$

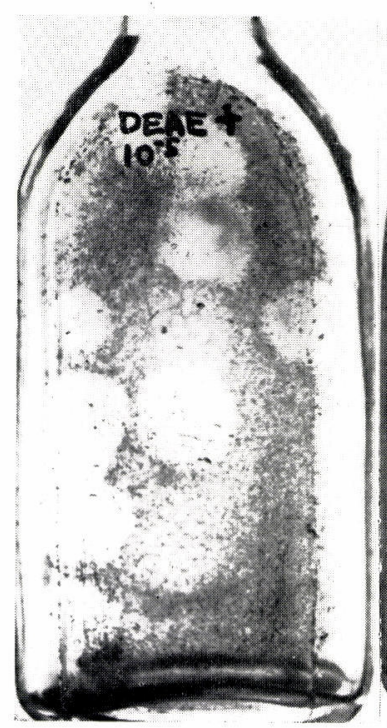

Dilution:

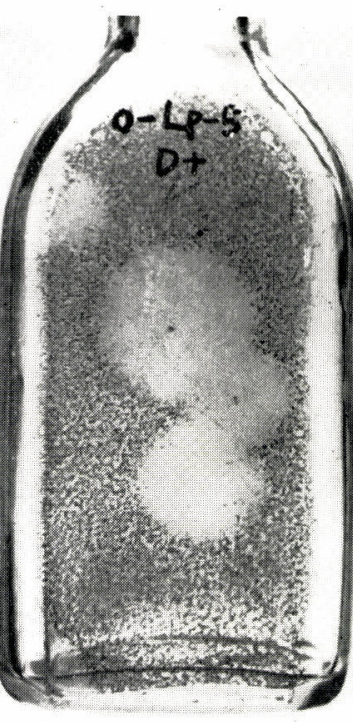

$10^{-5}$

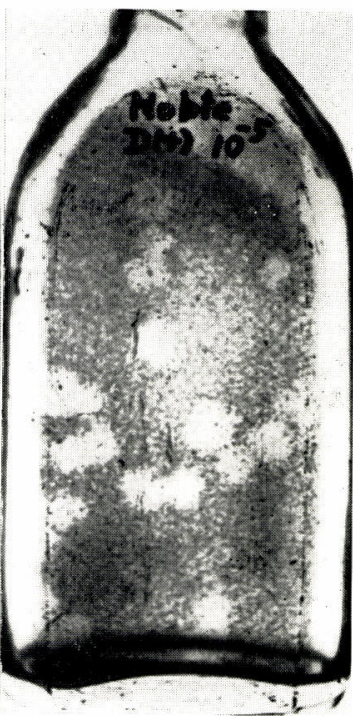

$10^{-5}$

Fig. 2. Plaques produced by the parent $(\mathrm{KH}), \mathrm{LP}$ and $\mathrm{SP}$ viruses of $\mathrm{AB}-\mathrm{IV}$ strain on MK monolayers under Noble-agar overlay of medium 199 on the 6th day after inoculation. Left to right: AB-IV-KH, AB-IV-LP and AB-IV-SP viruses in the indicated dilutions, respectively. Top: the overlay contained no DEAEdextran. Bottom: the overlay contained $100 \mu \mathrm{g} / \mathrm{ml}$ of DEAE-dextran. 
Table 2. Distribution of plaque sizes of coxsackie A7, AB-IV-KH strain in MK cells under Noble-agar overlay

\begin{tabular}{|c|c|c|c|c|c|c|c|c|c|c|c|}
\hline \multirow{2}{*}{$\begin{array}{l}\text { Exp. } \\
\text { No. }\end{array}$} & \multirow{2}{*}{$\begin{array}{l}\text { Number of } \\
\text { plaques } \\
\text { counted }\end{array}$} & \multicolumn{10}{|c|}{$\begin{array}{c}\text { Percent distribution of plaques of } \\
\text { diameter }(\mathrm{mm})\end{array}$} \\
\hline & & $\leq 1$ & 2 & 3 & 4 & 5 & 6 & 7 & 8 & 9 & 10 \\
\hline 1 & 106 & 69 & 14 & 9 & 2 & 0 & 3 & 0 & 0 & 2 & 1 \\
\hline 2 & 69 & 84 & 7 & 4 & 0 & 3 & 0 & 2 & 0 & 0 & 0 \\
\hline 3 & 74 & 49 & 16 & 8 & 3 & 11 & 7 & 5 & 1 & 0 & 0 \\
\hline
\end{tabular}

Plaque counting was carried out on the 5th day.

The standard agar overlay consisted of $1.5 \%$ Noble-agar and medium 199 supplemented with $0.1 \% \mathrm{BAFV}$ and $0.22 \%$ sodium bicarbonate.

The same virus stock was used for Exp. 1 and 2, and another stock for Exp. 3.

\section{RESULTS}

Variation in Plaque Size by AB-IV Strain of Coxsackievirus A 7 and Isolation of Large-plaque Producing $(L P)$ and Small-plaque Producing (SP) Viruses

Plaque formation of the AB-IV strain was examined at different passage levels. The AB-IV-KH 24351 strain produced plaques, heterogeneous in size, under Nobleagar overlay, including large plaques in a small proportion (Fig. 2). Only minute plaques, however, were produced by the same virus under Bacto-agar overlay. The $\mathrm{AB}-\mathrm{IV}-\mathrm{CH}$ and AB-IV-2812 produced minute plaques, if any, under Noble-agar and none under Bacto-agar overlay. Distribution of plaque sizes produced by AB-IV-KH 24351 strain under Noble-agar is shown in Table 2. Small or minute plaques constituted always major population; more than $50 \%$ of plaques were with diameters less than $1 \mathrm{~mm}$.

Isolation of two typical plaque formers were carried out, as described in the materials and methods (Fig. 1). The working stock of large-plaque producing (LP) and small-plaque producing (SP) viruses thus prepared produced almost homogeneous plaques. The genetic stability of LP and SP viruses in regard to plaque size was examined. As shown in Table 3, SP virus was rather stable even after 8 serial undiluted passages, while LP virus was stable only when it underwent limiting dilution passages. When LP virus was subjected to serial undiluted passages, size distribution of plaques produced by the virus changed markedly and after 8 passages the ratio of large plaques was reduced to $37 \%$.

\section{Investigations on the Factors Affecting Plaque Formation}

Overlay and nutrient media. - As a nutrient medium Parker's synthetic medium 199 was superior to LE in supporting the development of much more and larger plaques. Noble-agar was superior to Bacto-agar (Table 4). A comparative test on the plating efficiency of LP virus of AB-IV strain with 4 solidifying substances was carried out and the results are shown in Table 5 . The best results were obtained with Nobleagar and starch gel, while Bacto-agar was inferior. From the above-stated results, medium 199 containing $1.5 \%$ Noble-agar was used as a standard overlay. 
Table 3. Plaque properties of coxsackie A7, AB-IV-LP and AB-IV-SP viruses after diluted or undiluted serial passages

\begin{tabular}{|c|c|c|c|c|c|c|}
\hline \multirow{2}{*}{ Virus } & \multirow{2}{*}{$\begin{array}{l}\text { Passage } \\
\text { history }\end{array}$} & \multirow{2}{*}{$\begin{array}{l}\text { Appearance } \\
\text { of plaques }\end{array}$} & \multicolumn{4}{|c|}{ Diameter of plaques } \\
\hline & & & Range (mm) & Mean $(\mathrm{mm})$ & & atio $(\%)$ \\
\hline \multirow[t]{3}{*}{ AB-IV-LP } & $\begin{array}{l}\text { Starting } \\
\text { virus }\end{array}$ & $\begin{array}{l}\text { almost homogeneous, } \\
\text { large plaques }\end{array}$ & $6-11$ & 8.1 & 100 & $(16 / 16)$ \\
\hline & $\begin{array}{l}7 \text { diluted } \\
\text { passages }\end{array}$ & $\begin{array}{l}\text { almost homogeneous, } \\
\text { large plaques }\end{array}$ & $7-11$ & 8.3 & 100 & $(29 / 29)$ \\
\hline & $\begin{array}{l}8 \text { undiluted } \\
\text { passages }\end{array}$ & $\begin{array}{l}\text { varied in size, } \\
\text { large plaques } \\
\text { small plaques }\end{array}$ & $\begin{array}{l}6-10 \\
1-2\end{array}$ & $\begin{array}{l}8.3 \\
1.1\end{array}$ & $\begin{array}{l}37 \\
63\end{array}$ & $\begin{array}{l}(23 / 62) \\
(39 / 62)\end{array}$ \\
\hline \multirow[t]{2}{*}{ AB-IV-SP } & $\begin{array}{l}\text { Starting } \\
\text { virus }\end{array}$ & $\begin{array}{l}\text { almost homogeneous, } \\
\text { small plaques }\end{array}$ & $1-2$ & 1.0 & 100 & $(190 / 190)$ \\
\hline & $\begin{array}{l}8 \text { undiluted } \\
\text { passages }\end{array}$ & $\begin{array}{l}\text { almost kamegeneous, } \\
\text { large plaques } \\
\text { small plaques }\end{array}$ & $\begin{array}{l}6-8 \\
1-5\end{array}$ & $\begin{array}{l}7.0 \\
1.1\end{array}$ & & $\begin{array}{r}(4 / 345) \\
(341 / 345)\end{array}$ \\
\hline
\end{tabular}

Diluted passages were carried out by serial 7 limiting dilution passages in MK tube cultures.

Undiluted passages were done serially 8 times in MK tube cultures.

The standard overlay was used for the plaque formation.

Plaque counting was carried out on the 5 th day.

Figures in parentheses indicate the number of large or small plaques per total number examined.

Table 4. Comparison of plaquing efficiency between medium 199 and LE with Bacto-agar or Noble-agar

\begin{tabular}{|c|c|c|c|c|c|}
\hline \multirow{3}{*}{$\begin{array}{l}\text { Exp. } \\
\text { No. }\end{array}$} & \multirow{3}{*}{$\begin{array}{l}\text { Agar in } \\
\text { overlay }\end{array}$} & \multicolumn{4}{|c|}{ Medium } \\
\hline & & \multicolumn{2}{|r|}{ LE } & \multicolumn{2}{|c|}{199} \\
\hline & & $\begin{array}{c}\text { PFU per } \\
\text { bottle* }\end{array}$ & $\begin{array}{l}\text { Maximum } \\
\text { diameter }(\mathrm{mm})\end{array}$ & $\begin{array}{l}\text { PFU per } \\
\text { bottle* }\end{array}$ & $\underset{\text { diameter }(\mathrm{mm})}{\text { Maximum }}$ \\
\hline 1 & $\begin{array}{c}\text { Bacto-agar } \\
1.5 \%\end{array}$ & 1.2 & 1.0 & 8.2 & 2.6 \\
\hline 2 & $\begin{array}{c}\text { Noble-agar } \\
1.5 \%\end{array}$ & 12.0 & 2.0 & 47.0 & 4.5 \\
\hline
\end{tabular}

* Average number of the total plaques counted in 5 bottles.

** Average diameter of the largest plaque from each of 5 bottles.

AB-IV-KH, 24351 was used in these experiments.

Sodium bicarbonate concentration of the overlay. - As shown in Table 6 , SP virus did not produce plaques at sodium bicarbonate concentrations lower than $0.11 \%$ under either Noble or Bact-agar overlay, while LP virus produced plaques under Noble-agar overlay containing $0.11 \%$ sodium bicarbonate. The concentration of sodium bicarbonate for the most efficient plaque formation is considered to be from $0.22 \%$ to $0.33 \%$ for both LP and SP viruses. Effect on plaque formation of $0.22 \%$ sodium bicarbonate 
Table 5. Comparison of plaquing efficiency of AB-IV-LP virus under various overlays

\begin{tabular}{|c|c|c|c|c|c|}
\hline \multirow[b]{2}{*}{ Overlay } & \multicolumn{3}{|c|}{ PFU/bottle* } & \multicolumn{2}{|c|}{ Diameter $(\mathrm{mm})$} \\
\hline & $10^{-4}$ & $\begin{array}{l}\text { Virus dilution } \\
10^{-5}\end{array}$ & $10^{-6}$ & Average** & Maximum $^{* * *}$ \\
\hline $\begin{array}{c}\text { Bacto-agar } \\
1.5 \%\end{array}$ & 142.8 & 20.6 & 1.2 & 1.1 & 2.6 \\
\hline $\begin{array}{c}\text { Noble-agar } \\
1.5 \%\end{array}$ & confluent & 29.8 & 3.2 & 5.7 & 7.7 \\
\hline $\begin{array}{l}\text { Carboxy-methyl } \\
\text {-cellulose } 1.8 \%\end{array}$ & confluent & 23.8 & 3.6 & 2.5 & 3.2 \\
\hline $\begin{array}{c}\text { Starch gel } \\
10 \%\end{array}$ & confluent & 31.8 & 6.8 & 4.4 & 6.2 \\
\hline
\end{tabular}

* Average number of the total plaques counted in 5 bottles.

** Average diameter of the total plaques counted in 5 bottles.

*** Average diameter of the largest plaque from each of 5 bottles.

Nutrient medium in overlay consisted of medium 199 supplemented with $0.22 \%$ of sodium bicarbonate and $0.1 \%$ of BAFV.

Table 6. Effect of sodium bicarbonate on plaque formation by $\mathrm{AB}-\mathrm{IV}-\mathrm{SP}$ and $\mathrm{AB}-\mathrm{IV}-\mathrm{LP}$ viruses

\begin{tabular}{|c|c|c|c|c|c|c|c|}
\hline \multirow{3}{*}{ Virus } & \multirow{3}{*}{$\begin{array}{c}\text { Concentration } \\
\text { of } \mathrm{NaHCO}_{3}(\%)\end{array}$} & \multicolumn{3}{|c|}{ Noble-agar } & \multicolumn{3}{|c|}{ Bacto-agar } \\
\hline & & \multirow{2}{*}{$\underset{\text { bottle* }}{\text { PFU per }}$} & \multicolumn{2}{|c|}{ Diameter $(\mathrm{mm})$} & \multirow{2}{*}{$\begin{array}{l}\text { PFU per } \\
\text { bottle* }\end{array}$} & \multicolumn{2}{|c|}{ Diameter $(\mathrm{mm})$} \\
\hline & & & Range & Maximum** & & Range & Maximum** \\
\hline \multirow[t]{4}{*}{ AB-IV-SP } & 0.055 & 0 & - & - & 0 & - & - \\
\hline & 0.11 & 0 & - & - & 0 & - & - \\
\hline & 0.22 & 16.2 & $1 \sim 2$ & 2.0 & 4.0 & $<1$ & $<1$ \\
\hline & 0.33 & 15.2 & $1 \sim 2$ & 2.0 & 5.3 & $<1$ & $<1$ \\
\hline \multirow[t]{5}{*}{ AB-IV-LP } & 0.055 & 0 & - & - & 0 & - & - \\
\hline & 0.11 & 12.5 & $1 \sim 2$ & 1.5 & 0 & - & - \\
\hline & 0.22 & 18.0 & $7 \sim 12$ & 10.0 & 18.0 & $3 \sim 7$ & 5.0 \\
\hline & 0.33 & 13.5 & $8 \sim 13$ & 11.5 & 16.0 & $3 \sim 8$ & 6.0 \\
\hline & 0.44 & 24.5 & $5 \sim 9$ & 8.0 & 14.0 & $3 \sim 8$ & 6.7 \\
\hline
\end{tabular}

Overlays consisted of $1.5 \%$ agar and medium 199 supplemented with $0.1 \%$ BAFV and sodium bicarbonate at specified concentrations.

Plaques were observed on the 5 th day.

* Average plaque number of the total plapues counted in 4 bottles.

** Average of the diameters of the largest plaque from each of 4 bottles.

was compared with those of $12.5 \mathrm{mM}$ tris and $33 \mathrm{mM}$ phosphate buffers (Table 7). At the comparable $\mathrm{pH}$ values sodium bicarbonate was superior at least in regard to the plaque size.

Influence of the agar inhibitor. - It was demonstrated that production of plaques by 
Table 7. Comparison of the effects on plaque formation of $\mathrm{pH}$ adjusting buffers in the agar overlays

\begin{tabular}{lcccl}
\hline Buffer & $\mathrm{pH}^{*}$ & PFU/bottle & $\begin{array}{c}\text { Average } \\
\text { diameter }(\mathrm{mm})\end{array}$ & $\begin{array}{l}\text { Appearance } \\
\text { of plaques }\end{array}$ \\
\hline Tris & 7.9 & 17.8 & 2.4 & almost clear \\
Tris & 7.4 & 2.5 & 1.7 & not clear \\
Phosphate & 7.3 & 27.5 & 2.6 & $\begin{array}{l}\text { clear } \\
\text { cells tended } \\
\text { to degenerate }\end{array}$ \\
Phosphate & 6.5 & 0 & 0 & \\
$\begin{array}{l}\text { Sodium } \\
\text { bicarbonate }\end{array}$ & & & & clear and \\
$0.22 \%$ & 7.5 & 26.0 & 7.0 & homogeneous \\
\hline
\end{tabular}

AB-IV-LP virus was used in this experiment.

The overlay contained $1.5 \%$ Noble-agar and medium 199 supplemented with $0.1 \%$

BAFV and a buffer indicated.

* $\mathrm{pH}$ of the buffered nutrient medium was measured immediately before an equal volume of $3 \%$ agar solution was mixed.

Table 8. Effects of DEAE-dextran and protamine sulfate on the plaque formation of $\mathrm{AB}-\mathrm{IV}-\mathrm{SP}$ virus

\begin{tabular}{lcccc}
\hline Drug & $\begin{array}{c}\text { Conc. of } \\
\text { drug } \\
(\mu \mathrm{g} / \mathrm{ml})\end{array}$ & $\begin{array}{c}\text { Number of } \\
\text { plaques } \\
\text { per bottle* }\end{array}$ & $\begin{array}{c}\text { Diameter of plaques } \\
\text { Range (mm) }\end{array}$ & $\begin{array}{c}\text { Average } \\
\text { maximum (mm)** }\end{array}$ \\
\hline DEAE-dextran & 400 & 13.3 & $10-14$ & 13.6 \\
& 100 & 12.6 & $9-11$ & 10.0 \\
& 25 & 17.0 & $1-2$ & 2.0 \\
\hline protamine sulfate & 0 & 14.0 & $1-2$ & 1.5 \\
& $800^{* * *}$ & 20.0 & $5-9$ & $\mathrm{Ca} 9.5$ \\
& 400 & 40.0 & $6-8$ & 7.2 \\
& 200 & 33.6 & $3-5$ & 4.2 \\
& 100 & 5.4 & $2-3$ & 2.0 \\
& 50 & 5.6 & $1-2$ & 1.2 \\
& 0 & 7.2 & $1-2$ & 1.5 \\
\hline
\end{tabular}

The overlay consisted of $1.5 \%$ Noble-agar and medium 199 supplemented with $0.1 \% \mathrm{BAFV}, 0.22 \%$ sodium bicarbonate and an indicated concentration of the drugs.

* Average number of the total plaques from 3 to 5 bottles on the 6 th day.

** Average diameter of the largest plaque from each of 3 to 5 bottles.

*** Slightly cytotoxic.

the AB-IV-KH strain, especially SP virus, was enhanced remarkably in both number and size by the addition of 100 to $400 \mu \mathrm{g} / \mathrm{ml}$ of DEAE-dextran or 200 to $400 \mu \mathrm{g} / \mathrm{ml}$ of protamine sulfate to the overlay (Table 8). Plaque formation by LP virus was also enhanced by these drugs, but not so much as with SP virus. Inhibitory action 
Table 9. Inhibitory effects of Bacto-agar extract, dextran sulfate and heparin sodium on the plaque production by AB-IV-LP virus

\begin{tabular}{|c|c|c|c|c|c|}
\hline \multirow{2}{*}{\multicolumn{2}{|c|}{$\begin{array}{l}\text { Concentration } \\
\text { of inhibitor } \\
(\mu \mathrm{g} / \mathrm{ml})\end{array}$}} & \multicolumn{2}{|c|}{ Exp. 1} & \multicolumn{2}{|c|}{ Exp. 2} \\
\hline & & $\mathrm{PFU} /$ bottle* (\%) & \multirow{2}{*}{$\begin{array}{l}\text { Maximum** } \\
\text { diameter } \\
(\mathrm{mm})\end{array}$} & \multirow{2}{*}{$\frac{\mathrm{PFU} / \mathrm{bottle*}(\%)}{32.4(99)}$} & \multirow{2}{*}{$\begin{array}{c}\begin{array}{c}\text { Maximum** } \\
\text { diameter } \\
(\mathrm{mm})\end{array} \\
7.5\end{array}$} \\
\hline Bacto- & 40 & ND & & & \\
\hline agar & 200 & ND & & $29.5 \quad(91)$ & 6.2 \\
\hline \multirow[t]{4}{*}{ extract } & 250 & 16.8 (88) & 7.0 & $\mathrm{ND}$ & \\
\hline & 500 & $13.6(71)$ & 5.5 & ND & \\
\hline & 1,000 & $8.0 \quad(42)$ & 4.4 & $12.6(39)$ & 4.4 \\
\hline & 2,000 & $0 \quad(0)$ & 0 & ND & \\
\hline \multirow{4}{*}{$\begin{array}{l}\text { Dextran } \\
\text { sulfate }\end{array}$} & 25 & ND & & $25.0 \quad(77)$ & 7.0 \\
\hline & 50 & 3.4 (18) & 3.0 & $10.4(32)$ & 4.0 \\
\hline & 100 & 2.4 (13) & 2.0 & $5.6 \quad(17)$ & 3.2 \\
\hline & 200 & $0 \quad(0)$ & 0 & $0 \quad(0)$ & 0 \\
\hline \multirow{3}{*}{$\begin{array}{l}\text { Heparin } \\
\text { sodium }\end{array}$} & 1,000 & $21.0(109)$ & 9.6 & ND & \\
\hline & 2,000 & $11.2(58)$ & 7.2 & ND & \\
\hline & 4,000 & $4.6 \quad(24)$ & 3.2 & ND & \\
\hline Control & 0 & $19.2(100)$ & 8.9 & $32.6(100)$ & 7.6 \\
\hline
\end{tabular}

The overlay consisted of $1.5 \%$ Noble-agar and medium 199 supplemented with $0.1 \% \mathrm{BAFV}, 0.22 \%$ sodium bicarbonate and an indicated concentration of the inhibitors.

* Average number of the total plaques from 5 bottles counted on the 6th day.

** Average diameter of the largest plaque from each of 5 bottles.

Table 10. Comparative assay of the infectivities of coxsackie A7 viruses between the plaque and the tube methods

\begin{tabular}{lccc}
\hline \multirow{2}{*}{ Virus } & \multicolumn{2}{c}{ Infectivity } & $\begin{array}{c}\text { Plating } \\
\text { efficiency } \\
\text { PFU/TCID }_{50}\end{array}$ \\
\cline { 2 - 3 } & $\log \mathrm{PFU} / 0.2 \mathrm{ml}$ & $\log \mathrm{TCID}_{50} / 0.2 \mathrm{ml}$ & 0.25 \\
AB-IV-LP & 5.64 & 6.24 & 1.00 \\
AB-IV-SP & 6.26 & 6.27 & 0.30 \\
AB-IV-CH & 5.88 & 6.32 & 0.08 \\
Moscow-119 & 6.43 & 7.50 & 0.32 \\
Natori-32 & 6.52 & 7.02 & 0.18 \\
Z-C-52-7 & 5.57 & 6.31 & 0.10 \\
NYS-58182 & 5.51 & 6.51 & \\
\hline
\end{tabular}

The standard agar overlay was used for AB-IV-LP virus and $100 \mu \mathrm{g} / \mathrm{ml}$ of DEAEdextran was also incorporated in the overlay for the other strains.

The maintenance medium for tube assay was LE supplemented with $0.22 \%$ sodium bicarbonate. 


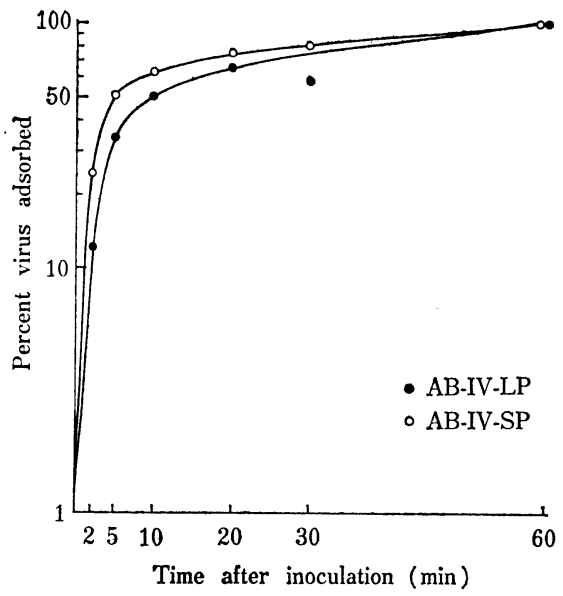

Fig. 3. Adsorption of AB-IV-LP and AB-IV-SP viruses to $\mathrm{MK}$ cells. $\mathrm{MK}$ bottle cultures were infected with $0.2 \mathrm{ml}$ of each appropriate dilution of the virus and incubated at $36 \mathrm{C}$. At specified times after inoculation 5 bottles were taken out and added with the standard agar overlay. Plaques produced were counted after further incubation at $36 \mathrm{C}$ for 6 days. Before addition of overlay the inoculum was not eliminated by washing, because no differences in plaque counts were observed between washed and unwashed cultures. In the overlay for SP virus $100 \mu \mathrm{g} / \mathrm{ml}$ of DEAE-dextran was added. The inoculum doses were $23.5 \mathrm{PFU} / 0.2 \mathrm{ml}$ for $\mathrm{LP}$ virus and $25.4 \mathrm{PFU} / 0.2 \mathrm{ml}$ for $\mathrm{SP}$ virus.
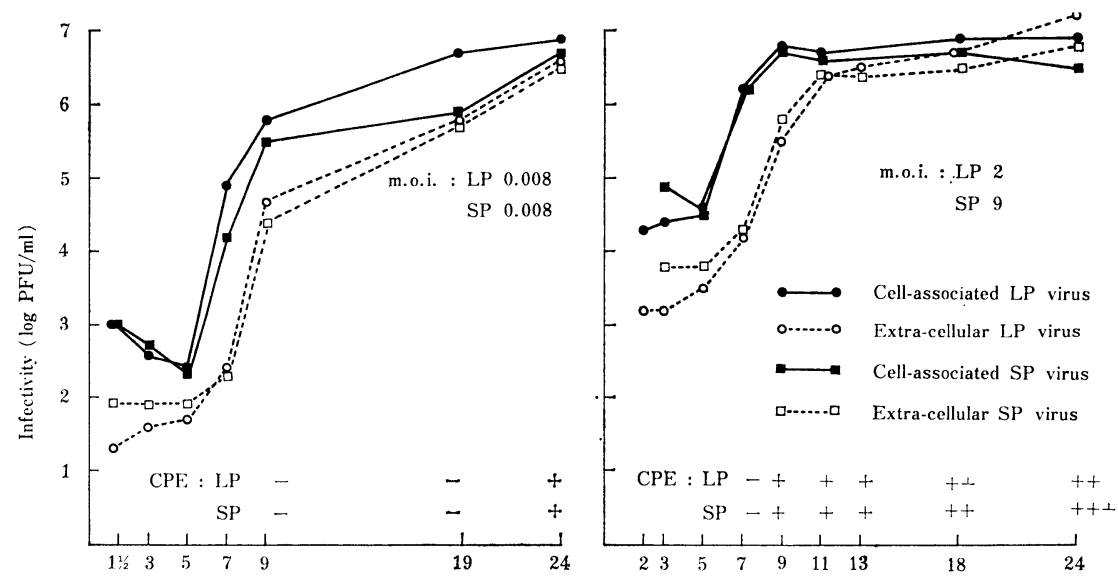

Time after virus inoculation (hr)

Fig. 4. Growth of AB-IV-LP and AB-IV-SP viruses in MK cells. Two-tenths $\mathrm{ml}$ of each appropriately diluted virus was inoculated into $2 \mathrm{oz}$. bottle MK cell cultures. Immediately after virus adsorption at $36 \mathrm{C}$ for $1 \mathrm{hr}$, the inoculum was eliminated by washing with $5 \mathrm{ml}$ of LE, and then fresh maintenance medium (serum free LE) was added in $5 \mathrm{ml} /$ bottle, being followed by incubation at $36 \mathrm{C}$. At time intervals indicated aliquots of 2 bottle cultures was harvested. The fluid was pooled, centrifuged at $3,000 \mathrm{rpm}$ for $10 \mathrm{~min}$ and the supernatant served as the extra-cellular virus sample. The cell sheets were washed with $\mathrm{LE}$ and then fresh medium in an equal amount as the maintenance medium was added. The cultures underwent freezing-thawings, then clarified by centrifugation at $3,000 \mathrm{rpm}$ for $10 \mathrm{~min}$, and the supernatant served as the cell-associated virus sample. The infectivity of each sample was titrated by the standard plaque method with Noble-agar overlay with $100 \mu \mathrm{g} / \mathrm{ml}$ of DEAE-dextran only for SP virus. 
Table 11. Cross neutralization of AB-IV-LP and AB-IV-SP viruses

\begin{tabular}{lccccc}
\hline \multicolumn{2}{c}{ Serum } & & & \multicolumn{3}{c}{ Antibody titer against AB-IV } \\
\cline { 5 - 6 } \cline { 5 - 6 } Virus & Code No. & & LP & SP & KH \\
\hline \multirow{2}{*}{ AB-IV-LP } & SR-15 & & 128 & 128 & 64 \\
& SR-16 & & 512 & 256 & 1500 \\
\hline \multirow{2}{*}{ AB-IV-SP } & SR-19 & & 128 & 128 & 96 \\
& SR-20 & & 512 & 166 & 256 \\
& SR-21 & & 190 & 128 & 96 \\
\hline \multirow{2}{*}{ AB-IV-KH } & SR- 4 & & $2048^{*}$ & $1024^{*}$ & 1520 \\
\hline
\end{tabular}

Antibody assay was carried out by the tube method; antibody titer was expressed as a reciprocal of the serum dilution showing $50 \%$ neutralization.

* Antibody titer was measured by the $90 \%$ plaque reduction method.

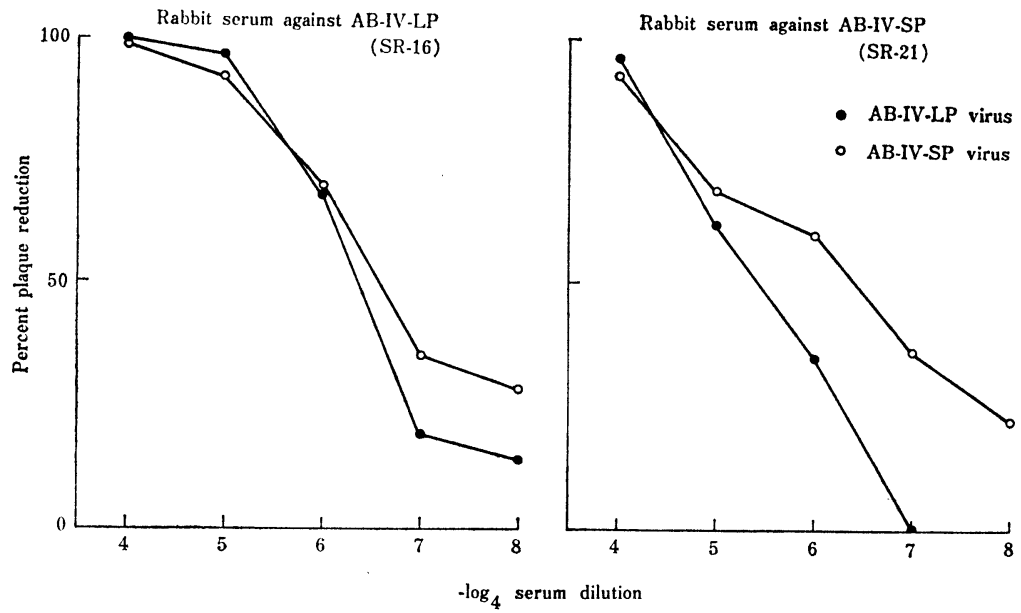

Fig. 5. Cross neutralization of AB-IV-LP and AB-IV-SP viruses by the plaque reduction method. The neutralization test was carried out as described in materials and methods. Rabbit immune sera against AB-IV-LP virus (SR16) and AB-IV-SP virus (SR-21) were inactivated at $56 \mathrm{C}$ for $30 \mathrm{~min}$ and diluted serially by 4 -fold. The infective doses of the challenge viruses were 105 $\mathrm{PFU} / 0.1 \mathrm{ml}$ for $\mathrm{AB}-\mathrm{IV}-\mathrm{LP}$ virus and $155 \mathrm{PFU} / 0.1 \mathrm{ml}$ for AB-IV-SP virus. The standard agar overlay was employed and $100 \mu \mathrm{g} / \mathrm{ml}$ of DEAE-dextran was added for SP virus.

of dextran sulfate, heparin sodium and agar extract prepared from Bacto-agar was shown with LP virus (Table 9). The lower the concentration of sodium bicarbonate, the more marked the inhibitory action of these substances. When Bacto-agar extract was added to the fluid of AB-IV virus-infected $\mathrm{MK}$ cultures, the growth of virus as well as the development of CPE delayed.

The standard plaque technique thus established provided a linear correlation between the virus dilution and the plaque number. With Noble-agar overlay containing 
Table 12. Detection of pathogenicity in newborn mice of various strains of coxsackievirus $A 7$

\begin{tabular}{|c|c|c|c|c|}
\hline \multicolumn{2}{|c|}{ Virus* } & \multirow{2}{*}{$\begin{array}{l}\text { Route of } \\
\text { inoculation }\end{array}$} & \multicolumn{2}{|c|}{ Number of mice } \\
\hline $\begin{array}{l}\text { Strain } \\
\text { name }\end{array}$ & $\begin{array}{l}\text { Infectivity** } \\
\text { per } \mathrm{ml}\end{array}$ & & inoculated & paralyzed $* * * *$ \\
\hline AB-IV-KH & $10^{7.4}$ & s. c. & 6 & 0 \\
\hline " & $\prime \prime$ & i. c. & 6 & 0 \\
\hline AB-IV-LP & $10^{6.9}$ & s. c. & 7 & 0 \\
\hline AB-IV-SP & $10^{7.0}$ & s. c. & 7 & 0 \\
\hline Hale & $10^{7.0}$ & s. c. & 4 & 0 \\
\hline NYS-58180 & $10^{7.0}$ & s. c. & 3 & 0 \\
\hline NYS-58182 & $10^{7.2}$ & s. c. & 5 & 0 \\
\hline Parker & $10^{2.5}$ & s. c. & 3 & 3 \\
\hline " & $\prime \prime$ & i. c. & 4 & 4 \\
\hline \multicolumn{2}{|c|}{$\begin{array}{l}\text { uninfected control } \\
\text { with medium LE }\end{array}$} & s. c. & 3 & 0 \\
\hline $\begin{array}{ll}* & \text { Virus } \\
& \text { Table } \\
* * & \text { Infect } \\
& \text { LD }_{50} / \\
* * * & \text { s. c. } \\
* * * * & \begin{array}{l}\text { Parke } \\
\text { viruse }\end{array}\end{array}$ & $\begin{array}{l}\text { sed in this exp } \\
\text { except Parker } \\
\text { es are expresse } \\
\text { or Parker stra } \\
\text { cutaneously in } \\
\text { ain induced pa } \\
\text { ve no sign wi }\end{array}$ & $\begin{array}{l}\text { nt are MK-cell a } \\
\mathrm{n} \text { which is newbo } \\
\mathrm{TCID}_{50} / \mathrm{ml} \text { for } \\
\mathrm{ml} \text {, i. c. : intrace } \\
4 \text { to } 5 \text { days aft } \\
4 \text { days. }\end{array}$ & $\begin{array}{l}\text { ed viruses, a } \\
\text { mice passed } \\
\text { cell adapted } \\
\text { ally in } 0.02 \mathrm{n} \\
\text { noculation, w }\end{array}$ & \\
\hline
\end{tabular}

DEAE-dextran at a concentration of $100 \mu \mathrm{g} / \mathrm{ml}$, the other strains of coxsackievirus A 7 could also be titrated by the plaque technique, but generally the tube method was more efficient as shown in Table 10 .

\section{Biological Properties of $L P$ and SP Viruses of AB-IV Strain}

Adsorption to and viral growth in MK cells. - Figure 3 illustrates that both LP and $\mathrm{SP}$ viruses are adsorbed onto primary $\mathrm{MK}$ cells at nearly the same rate; more than $50 \%$ of the inoculum was adsorbed with $10 \mathrm{~min}$ and the adsorption was almost complete in $60 \mathrm{~min}$. Replicate experiments, however, suggested that SP virus always tended to be adsorbed onto MK cells a little faster than LP virus, as was observed in Fig. 3. No differences in the mode of viral growth in MK cell cultures were observed detween LP and SP viruses either at a high or low multiplicity of infection, as shown in Fig. 4.

Results of cross neutralization tests. - Serological relationship among LP, SP and the parent viruses of AB-IV strain was examined by cross neutralization tests. As shown in Table 11, the titers tended to fluctuate much more than those with LP and SP viruses when the parent $\mathrm{KH}$ virus was used in the antibody titration, however, as a whole, rabbit immune sera against each strain neutralized homologous and heterologous strains nearly to the same extent. Plaque neutralization curves of LP and SP viruses with anti-LP and anti-SP rabbit immune sera also indicated no significant difference 
Table 13. Plaque formation by coxsackie A7 strains under various overlays

\begin{tabular}{|c|c|c|c|c|c|c|c|}
\hline \multicolumn{2}{|c|}{ Virus } & \multirow{2}{*}{\multicolumn{2}{|c|}{$\begin{array}{c}\text { Plaques under } \\
\text { Noble-agar } \\
\text { with DEAE-dextran }\end{array}$}} & \multicolumn{4}{|c|}{ Relative plaque number** under } \\
\hline \multirow{2}{*}{$\begin{array}{l}\text { Strain } \\
\text { name }\end{array}$} & \multirow{2}{*}{$\begin{array}{l}\text { Passage* } \\
\text { history } \\
\text { in cell } \\
\text { culture }\end{array}$} & & & \multirow{2}{*}{$\begin{array}{l}\text { Noble-agar } \\
\text { with } \\
\text { protamine } \\
\text { sulfate }\end{array}$} & \multirow{2}{*}{$\begin{array}{l}\text { Noble } \\
\text {-agar } \\
\text { only }\end{array}$} & \multirow{2}{*}{$\begin{array}{l}\text { Bacto } \\
\text {-agar }\end{array}$} & \multirow{2}{*}{$\begin{array}{l}\text { Carboxy } \\
\text {-methyl } \\
\text {-cellulose }\end{array}$} \\
\hline & & $\begin{array}{l}\text { Diameter } \\
\text { range }(\mathrm{mm})\end{array}$ & Appearance & & & & \\
\hline $\begin{array}{l}\text { AB-IV-KH, } \\
\text { No. } 24351\end{array}$ & MK 2 & $7-15$ & typical $* * *$ & ND & 34 & 24 & 65 \\
\hline AB-IV-LP & MK 7 & $10-18$ & typical & 92 & 74 & 72 & 31 \\
\hline AB-IV-SP & MK 8 & $5-10$ & typical & 79 & 95 & 24 & 94 \\
\hline AB-IV-CH & MK 1 & $8-14$ & typical & 109 & 0 & 0 & 115 \\
\hline AB-IV-2812 & MK 1 & $8-14$ & typical & 108 & 4 & 0 & 2 \\
\hline Parker-CDC & MK 6 & $12-20$ & typical & ND & 87 & $\mathrm{ND}$ & ND \\
\hline Parker-Moscow & $v$ MK 6 & $8-18$ & typical & ND & 57 & $\mathrm{ND}$ & ND \\
\hline $63-G-35-4$ & MK 5 & $3-10$ ir & rregular, faint & ND & 0 & 0 & 81 \\
\hline Natori-32 & MK 5 & $7-12$ & typical & 95 & 35 & 0 & 90 \\
\hline Z-C-52-7 & MK 5 & $6-11$ & typical & 104 & 10 & 0 & 16 \\
\hline Z-C-61-7 & MK 5 & $6-10$ & typical & 103 & 69 & 5 & 86 \\
\hline Moscow-119 & MK 1 & $7-12$ & typical & 78 & 43 & 0 & 19 \\
\hline Moscow-172 & MK 1 & $10-11$ & typical & 77 & 40 & 0 & 12 \\
\hline Hale & MK10 & $1-8$ & $\begin{array}{l}\text { hazy, } \\
\text { various sizes }\end{array}$ & 92 & 0 & 0 & 342 \\
\hline NYS-58180 & MK 9 & $1-3$ & faint & 0 & 0 & 0 & 0 \\
\hline NYS-58182 & MK10 & $3-8$ & faint & 15 & 0 & 0 & 72 \\
\hline $\begin{array}{r}* \quad \text { Passag } \\
\text { strains } \\
\text { histori } \\
* * \quad \text { Calcul } \\
100 \mu \mathrm{g} \\
\text { *** typical }\end{array}$ & $\begin{array}{l}\text { ge number } \\
\text { s of AB-IV } \\
\text { ies in our } \\
\text { lated from } \\
/ \mathrm{ml} \text { taken } \\
l: \text { round a }\end{array}$ & $\begin{array}{l}\text { MK cell cc } \\
\text { irus and Mc } \\
\text { poratory are } \\
\text { e plaque nu } \\
100 . \\
\text { clear plaqu }\end{array}$ & $\begin{array}{l}\text { Lultures includ } \\
\text { loscow- } 119 \text { and } \\
\text { described du } \\
\text { umber under } \\
\text { ues of almost }\end{array}$ & $\begin{array}{l}\text { ing purificati } \\
\text { Moscow } 17 \\
\text { e to uncertai } \\
\text { Noble-agar }\end{array}$ & $\begin{array}{l}\text { on proc } \\
2 \text { strain } \\
\text { in prece } \\
\text { with DF }\end{array}$ & $\begin{array}{l}\text { edures. } \\
\text { only } \\
\text { ling } h\end{array}$ & $\begin{array}{c}\text { For } 5 \\
\text { passage } \\
\text { histories. } \\
\text { extran at }\end{array}$ \\
\hline
\end{tabular}

as shown in Fig. 5.

Pathogenicity in newborn mice. - The parent virus of AB-IV strain failed to induce paralyses. Neither LP nor SP viruses were also pathogenic to newborn mice (Table 12).

\section{Plaque Formation by Various Coxsackievirus A 7 strains}

Plaque formation by various strains of coxsackievirus A 7 were examined in primary MK cell cultures under Noble-agar with or without DEAE-dextran or protamine sulfate, Bacto-agar or carboxy-methyl-cellulose overlay. The results are summarized in Table 13. Under Noble-agar without DEAE-dextran AB-IV-KH 24351 and two MK-adapted lines of the prototype Parker strain produced plaques of various sizes, while AB-IV-CH, 63-G-35-4, Hale, NYS-58180 and NYS-58182 failed to produce visible plaques. The other 6 strains, including AB-IV-2812, produced minute plaques 
of 1 to $2 \mathrm{~mm}$ in diameter. Most of the strains produced round, clear plaques of almost uniform size when DEAE-dextran at $100 \mu \mathrm{g} / \mathrm{ml}$ or protamine sulfate at $400 \mu \mathrm{g} / \mathrm{ml}$ was incorporated into Noble-agar overlay, but several strains such as 63-G-35-4, Hale, NYS58180 and NYS-58182 produced faint or hazy plaques of various sizes. Plaques produced under CMC overlay were variable; sometimes round and clear and sometimes small and faint.

\section{Discussion}

Koroleva et al. $(1967,1968)$ reported that MK cell-adapted CA 7 virus strains produced either very small or no plaques in MK cells under an overlay containing $0.9 \%$ Bacto-agar 'Difco', and considered anionic sulfated polysaccharide contained in agar inhibitorily affected plaque production by the virus. However, neither enhancing effect of DEAE-dextran on the plaque formation by CA 7 virus nor plaque formation under agarose or carboxy-methyl-cellulose could be observed. The present author obtained such different findings that three out of $14 \mathrm{CA} 7$ virus strains tested produced large plaques and that plaque-enhancing effect of DEAE-dextran or protamine sulfate was clearly demonstrated. These discrepancies in the results may partly be due to the fact that Koroleva et al. used a strain at far advanced passage levels in tissue cultures, studying the effect of DEAE-dextran on plaque formation under Bactoagar overlay.

As for the pathogenicity of CA 7 virus in suckling mice, Koroleva et al. (1968) found that the small plaque-forming parent virus was not pathogenic for baby mice, but the mutant virus forming middle-size plaques, which was obtained by serial passages of the parent virus in the presence of dextran sulfate, recovered the mouse pathogenicity. In the present studies the LP virus, which may be considered as relatively resistant to dextran sulfate, showed no pathogenicity to suckling mice. On the other hand, 3 out of 4 strains producing small plaques isolated in MK cells possessed mouse pathogenicity (Soda et al., 1966). Accordingly, the close correlation between dextran sulfate resistance and suckling mouse pathogenicity of CA 7 virus strains as suggested by Koroleva et al. could not be observed in the present study.

Concerning genesis of LP and SP viruses, two factors, mutation and selection, should be considered, whichever the parent virus might be. In the present study small plaque-forming viruses of AB-IV strain were found to constitute a major population, but large plaque-forming viruses might have been predominant at an early passage level in MK cells in the light of the findings that large plaques were observed only in the AB-IV strain at a lower passage level through MK cells and that the cloned LP virus tended to yield small plaque-forming viruses by serial undiluted passages through MK cells, while SP virus was stable. It has been reported with several enteroviruses that the host cell system often played a role in selecting mutants with different plaque morphology. In the present study CA 7 virus strains adapted only to $\mathrm{MK}$ cells were studied, and investigations on CA 7 virus isolated and subcultured only in other cell cultures, such as human diploid cells serving as sensitive indicators of $\mathrm{m}^{+}$virus (Suto, Karzon and Bussell, 1965), will contribute to elucidate these problems.

It has been reported with various enteroviruses that variants with different plaque morphology were characterized by different biological properties from the parent virus (Choppin and Eggers, 1962; Barron and Karzon, 1965; Suto et al., 1965; Suto, Karzon 
and Bussell, 1965; Barron and Karzon, 1961). In the case of AB-IV strain of CA 7 virus no significant differences were noticed between the LP and SP viruses in growth kinetics, release of mature virus from cells, cytopathogenicity in MK cells, and sensitivity to antibody. Although MK-cell adapted AB-IV strain was not pathogenic to suckling mice, there seems to be no correlation between plaque morphology and suckling mouse pathogenicity as evidenced with other CA 7 strains. The only obvious difference between the LP and SP viruses was the properties related to plaque formation, that is, plaque morphology under various overlays, sensitivity to agar inhibitor and polyanionic drugs such as dextran sulfate. As the plaque formation by SP virus was remarkably suppressed by the addition of Bacto-agar extract or polyanionic drugs such as dextran sulfate and reversely enhanced by polycationic substances such as DEAEdextran, the main factor responsible for plaque inhibition by CA 7 virus is considered to be sulfated polysaccharide contained in agar (Takemori and Nomura, 1960; Takemoto and Liebhaber, 1961).

\section{ACKNOWLEDGEMENTS}

The author is much indebted to Dr. Isamu Tagaya for his continuous encouragement and valuable advices in the performance of the present work. Thanks are also due to Mr. Akio Hagiwara and Miss Kyoko Odawara for their help to perform the work. This work was carried out in the Department of Enteroviruses, National Institute of Health, Tokyo, and the outline of this work was presented at the 13th annual meeting of the Society of Japanese Virologists, October 21, 1965, in Nagasaki.

\section{REFERENCES}

AGOL, V. I. AND Chumakova, M. YA. (1962): An agar polysaccharide and d marker of poliovirus. Virology, 17, 221-223.

BARRON, A. L. AND KARZON, D. T. (1961): Characteristics of echo 4 (Shropshire) virus isolated during epidemic of aseptic meningitis. J. Immunol., 87, 608-615.

BARRON, A. L. AND KARZON, D. T. (1965): Studies of mutants of echovirus 6. I. Biologic and serologic characteristics. Am. J. Epidemiol., 81, 323-332.

Choppin, P. W. AND EGgers, H. J. (1962): Heterogeneity of Coxsackie B4 virus: Two kinds of particles which differ in antibody sensitivity, growth rate, and plaque size. Virology, $18,470-476$.

Chumakov, M. P., Voroshilova, M. K., Zhevandrova, V. I., Mironova, L. L., Itzelis, F. G. AND ROBINSON, I. A. (1956): Isolation and study of immunologic type IV poliomyelitis virus. Probl. Virol., 1, 16-19.

DE MAEYeR, E. AND SCHONNE, E. (1964): Starch gel as an overlay for the plaque assay of animal viruses. Virology, 24, 13-18.

DUlbecco, R. AND VOGT, M. (1954): Plaque formation and isolation of pure lines with poliomyelitis viruses. J. Exptl. Med., 99, 167-182.

GRIST, N. R. AND ROBERTS, G. B. S. (1966): Coxsackie A 7 virus infections of rodents. Arch. Ges. Virusforsch., 19, 454-463.

HABEL, K. AND Loomis, L. N. (1957): Coxsackie A 7 virus and Russian " poliovirus type 4 ". Proc. Soc. Exptl. Biol. Med., 95, 597-605.

Koroleva, G. A., Frolova, M. P., Voroshilova, M. K. AND Robinson, I. A. (1967): Changes in neurovirulence of coxsackie viruses A 7, A 14 and A 16 dependent on passaging in cell cultures and animals. Acta Virol., 11, 78-88.

Koroleva, G. A., Lashievich, V. A., Voroshilova, M. K. AND Frolova, M. P. (1968): The effect of dextran sulfate upon plaque formation and virulence of coxsackie A 7, A 14 
and A 16 viruses. Arch. Ges. Virusforsch., 23, 175-193.

REED, L. J. AND MUENCH, H. (1938): A simple method of estimating fifty per cent endpoints. Am. J. Hyg., 27, 493-497.

SodA, K., Moritsugu, Y., Odawara, K., Hagiwara, A., Kodama, H. and Tagaya, I. (1966): Serological properties of Coxsackie A 7 virus. Nature, 211, 315-316.

Suto, T., Karzon, D. T., Bussell, R. H. And Barron, A. L. (1965): Studies of mutants of echovirus 6. II. Isolation from human alimentary tract. Am. J. Epidemiol., 81, 333340.

Suto, T., KARzon, D. T. AND Bussell, R. H. (1965): Studies of mutants of echovirus 6 . III. Behavior in monkey and human cell culture. Am. J. Epidemiol., 81, 341-349.

TAKEMORI, N. AND NOMURA, S. (1960): Mutation of polioviruses with respect to size of plaque. II. Reverse mutation of minute plaque mutant. Virology, 12, 171-184.

TAKemoto, K. K. AND Liebhaber, H. (1961): Virus-polysaccharide interactions. I. An agar polysaccharide determining plaque morphology of EMC virus. Virology, 14, 456-462.

Tytell, A. A. AND Neuman, R. E. (1963): A medium free of agar, serum and peptone for plaque assay of herpes simplex virus. Proc. Soc. Exptl. Biol. Med., 113, 343-346.

Voroshilova, M. K. AND Chumakov, M. P. (1959): Poliomyeltis-like properties of ABIV-Coxsackie A 7 group of viruses. Prog. Med. Virol., 2, 106-170. 